\title{
Milieubelastingen : alleen maar interessant voor een academisch debat
}

Citation for published version (APA):

bongaerts, J. C. (1996). Milieubelastingen : alleen maar interessant voor een academisch debat. Maastricht University. https://doi.org/10.26481/spe.19960705jb

Document status and date:

Published: 05/07/1996

DOI:

10.26481/spe.19960705jb

Document Version:

Publisher's PDF, also known as Version of record

\section{Please check the document version of this publication:}

- A submitted manuscript is the version of the article upon submission and before peer-review. There can be important differences between the submitted version and the official published version of record.

People interested in the research are advised to contact the author for the final version of the publication, or visit the DOI to the publisher's website.

- The final author version and the galley proof are versions of the publication after peer review.

- The final published version features the final layout of the paper including the volume, issue and page numbers.

Link to publication

\footnotetext{
General rights rights.

- You may freely distribute the URL identifying the publication in the public portal. please follow below link for the End User Agreement:

www.umlib.nl/taverne-license

Take down policy

If you believe that this document breaches copyright please contact us at:

repository@maastrichtuniversity.nl

providing details and we will investigate your claim.
}

Copyright and moral rights for the publications made accessible in the public portal are retained by the authors and/or other copyright owners and it is a condition of accessing publications that users recognise and abide by the legal requirements associated with these

- Users may download and print one copy of any publication from the public portal for the purpose of private study or research.

- You may not further distribute the material or use it for any profit-making activity or commercial gain

If the publication is distributed under the terms of Article $25 \mathrm{fa}$ of the Dutch Copyright Act, indicated by the "Taverne" license above, 
Universiteitsbibliotheek

Rijksuniversiteit Limburg

Postbus 616

6200 MD Maastricht

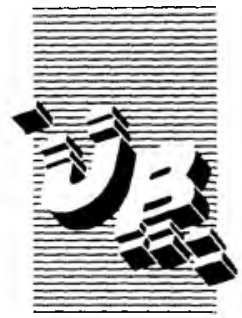

De uilleentermijn verstrijkt op:

\section{$160 \mathrm{KT} .1085$}

27 NoV 2000
Gelieve deze publicatie tijdig te retourneren of (telefonisch) verlenging van de uitleentermijn aan te vragen.

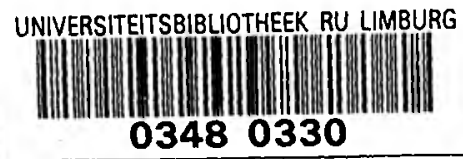




\title{
Milieubelastingen: alleen maar interessant
}

\author{
voor een academisch debat?
}

\section{Inleiding}

Een kwart eeuw geleden schreven (de latere Nobelprijswinnaar) W. Baumol, die hier, in 1996, in Maastricht, ter gelegenheid van de twintigste dies natalis viering een eredoctoraat ontving en W. Oates een bijdrage met als titel: The Use of Standards and Prices for the Protection of the Environment. ' Deze bijdrage wordt vandaag als baanbrekend beschouwd. ${ }^{2}$ Intussen zijn economen in binnen- en buitenland ervan overtuigd dat milieuheffingen, milieubelastingen en soortgelijke fiscale instrumenten veel beter geschikt zijn om de toestand van het milieu te behouden, te beschermen of te verbeteren dan administratief rechtelijke regels. De voordelen liggen klaarblijkelijk voor eenieders ogen:

- flexibiliteit: de belaste onderneming of consument wordt niet voorgeschreven hoe zij of hij dient te handelen;

- conformiteit met het principe dat de vervuiler betaalt: zelfs indien de milieuhefling wordt afgewenteld blijt gelden dat zij de kostencalculering van de betrokkene beïnvloedt;

- aangepast aan de logica van het bedrijfsleven, dat in termen van kosten en opbrengsten denkt en handelt;

- sturende werking met betrekking tot het gestelde en beoogde milieudoel;

- vereenvoudiging van de milieuwetgevingswerkzaamheden;

- vereenvoudiging van de milieuinspectie en -controle.

Overtuigender kan deze opsomming haast niet zijn en de milieuwetgevers en milieubeleidsmakers hebben alle argumenten ter hand om - in theorie - de bestaande milieuwetgeving net succes en met grote instemming van het bedrijfsleven en de publieke opinie te vervangen door een milieufiscaal rechtssysteem. Milieugerecht of milieuvriendelijk handelen wordt dan fiscaal beloond of tenminste niet belast. Milieuschadelijk of milieubedreigend handelen word dan fiscaal belast. De realiteit in de meeste lidstaten van de Europese Unie en elders ter wereld ziet er geheel anders uit: het aantal milieuheffingen en milieubelastingen is beperkt en het inkomstenniveau is gering. 
Geen enkel land heen op dit ogenblik een fiscaal stelsel dat op ecologisclie grondslagen is gebaseerd. Met dit laatste wordt bedoeld dat de overheidsinkomsten uitsluitend of grotendeels voortvloeien uit heffingen. belastingen en andere - soortgelijke - instrumenten die milieuschadelijke activiteiten trachten te beperken. De ecologische belastinghervorming schijnt overigens aan populariteit te verliezen. ${ }^{3} \mathrm{Het}$ milieubeleidsdebat heef een nieuw instrument ontdekt dat in de verscheidenheid van zijn talrijke facetten in relatie tot het milicuadministratief recht wordt ontleed. Dat instrument draagt voorlopig nog diverse namen: convenant (in Nederland), freiwillige Vereinbanung, freiwillige Selbstverplichtung (Duitsland), contrat de branche (Frankrijk), negotiated agreement (Europese Commissie).

De vraag rijst waarom milicuheffingen, milieubelastingen en ecn ecologische belastinghervorming ondanks de vele genoemde voordelen als milicubeleidsinstrumenten zo weinig populariteit genieten. Olaf Henkel, ooit „Ökomanager des Jahres" (als Chef van IBM Deutschland), stelde - in zijn huidige functie als chef van BDI (Bundesverband der Deutschen Industrie) - op een persconferentie einde Maart 1996 in het Bundeskanzleramt en in aanwezigheid van de duitse ministers voor milieu en economische zaken zelfs vast dat de eco-belastingen voor eens en voor altijd „vom Tisch“ waren. Historische uitspraken? Heeft de man gelijk? Moeten wij ervan uitgaan dat dit veelgeprezen instrument in de economisch belangrijkste lidstaat van de Europese Unie van de politieke agenda is verdwenen? Luidt de conclusie dat de economen hun pleidooi voor milieuheffingen en milieubelastingen, om niet te spreken over de ecologische belastinghervorming, tenminste in Europa, op lange termijn verloren hebben?

Mocht dit inderdaad zo blijken, dient evenzeer geconcludeerd te worden dat het intensief bedreven "consulting" van de milieueconomen in Europa zonder vruchten is gebleven. Dan stelt zich de vraag: waarom waren deze economen dan zo weinig effectief? Wat hebben zij niet voldoende in ogenschouw genomen? Plaatsgebrek laat niet toe een complete ,metaeconomische" verklaring voor dit échec te geven. Daartoe beschikken we overigens niet over alle gegevens. Enkele aspecten, die hierna behandeld worden, verdienen wellicht te worden beschouwd.

\section{Theorie van de milieuheffingen en milieubelasting}

\section{II.1 Systematiek}

Zonder een aanspraak op volledigheid te maken, lijkt het gepast om aan het begin een overzicht van milieuheffingen en milieubelastingen te presenteren. Voor een uitputtende en uiterst leerzame behandeling zijn hier verwezen naar het proefschrift van Aggie Paulus, dat ann deze Universiteit met succes werd verdedigd en - in mijn opvatting - als een

3 Dezelfde conclusic geldt evencens voor de zogenaande verhandelbare milicurechıcı. Ook zij zijn in Europa weinig verder geraikt dan ondenverp vall cen academiscil debal. 
waarachtige bijbel imtrent dit thema mag worden beschouwd. ${ }^{4}$ Ondanks het feit dat milieuheffingen en milieubelastingen vaak in een adem worden genoend bestaan er enkele duidelijke verschillen. Die hebben vooral betrekking op de doelstelling en de besteding van de inkomsten. Tabel 1 geeft de details weer.

Tabel 1: Milieuhefringen en milieubelastingen

\begin{tabular}{|c|c|c|}
\hline & Heffingen & Belastingen \\
\hline Doelstelling & $\begin{array}{l}\text { - Verbetering van het milieu } \\
\text { Publieke inkomsten voor } \\
\text { milieubeheer }\end{array}$ & $\begin{array}{l}\text { - Publieke inkomsten } \\
\text { - Verbetering van het milieu }\end{array}$ \\
\hline $\begin{array}{l}\text { Soorten en } \\
\text { benoeming }\end{array}$ & $\begin{array}{l}\text { Ressourcenheffing } \\
\text { Energieheffing } \\
\text { Uitworpheffing }\end{array}$ & $\begin{array}{l}\text { Ressourcenbelasting } \\
\text { Energiebelasting } \\
\text { Uitworpbelasting }\end{array}$ \\
\hline Besteding & $\begin{array}{l}\text { Milieubeheersmiddelen van de } \\
\text { publieke sector }\end{array}$ & Algemene middelen \\
\hline Sturende werking & $\begin{array}{l}\text { Verbetering van het milieu met } \\
\text { behulp van economische } \\
\text { instrumenten }\end{array}$ & $?$ \\
\hline Voorbeclden & $\begin{array}{l}\text { - Afvalheffing } \\
\text { - Afvalwaterheffing }\end{array}$ & $\begin{array}{l}\text { - Bezinebelasting } \\
\text { - } \mathrm{CO}_{2} \text {-belasting } \\
\text { - Energiebelasting }\end{array}$ \\
\hline
\end{tabular}

Ondanks het feit dat milieuheffingen en milieubelastingen beide als milieuverbeterende instrumenten worden beschouwd, valt op dat

- milieubelastingen in de eerste plaats een fiscaal doel hebben: inkomsten voor de staat bezorgen. Het milieueffect is daarbij meegenomen. Met betrekking tot milieuheffingen is de voorkeur andersom: het milieudoel staat op de eerste plats. Voor zover cr inkomsten worden verworven, zijn ze voor de uitvoering van het milicubeleid van de overheid voorbestemd.

- milieuheffingen in de eerste plaats het milieubeleid van de overheid ondersteunen. In deze zin kunnen ze als alternatief voor het administratief milieurecht worden opgevat.

Uit dit overzicht wordt indirect duidelijk, waarom milieuheffingen door de betrokkenen (bedrijfsleven, consumenten) - in tegenstelling tot milieubelastingen - met minder tegenzin geaccepteerd worden. Ten eerste zijn milieuhefringen als een alternatief instrument in vergelijking met milieuadministratieve voorschriften. voor de betrokkenen interessant. Het al 
genoemde voordeel van de flexibiliteit staat daarvoor borg Ten tweede kan de betrokkene ervan uitgaan dat de inkomsten aan de oplossing van het specificke milieuprobleem, waarmee hij te maken heeft en waarvoor hij betaalt, bestced worden Tenslotte kan vasigesteld worden dat een milicuheffing mettenijd "verzacht" wordt als blijkt dat het specifieke milieuprobleem meer en meer wordt opgelost

Het duitse model van de afvalwaterhething (Abwasserabgabe) illustreent dit vermoeden in alle duidelijkheid:

Figuur 1: het duitse "Abwasserabgabengesetz": nominale en gereducecrde tarieven van de afvalwaterhefring (in DNI per vervuilingseenheid)

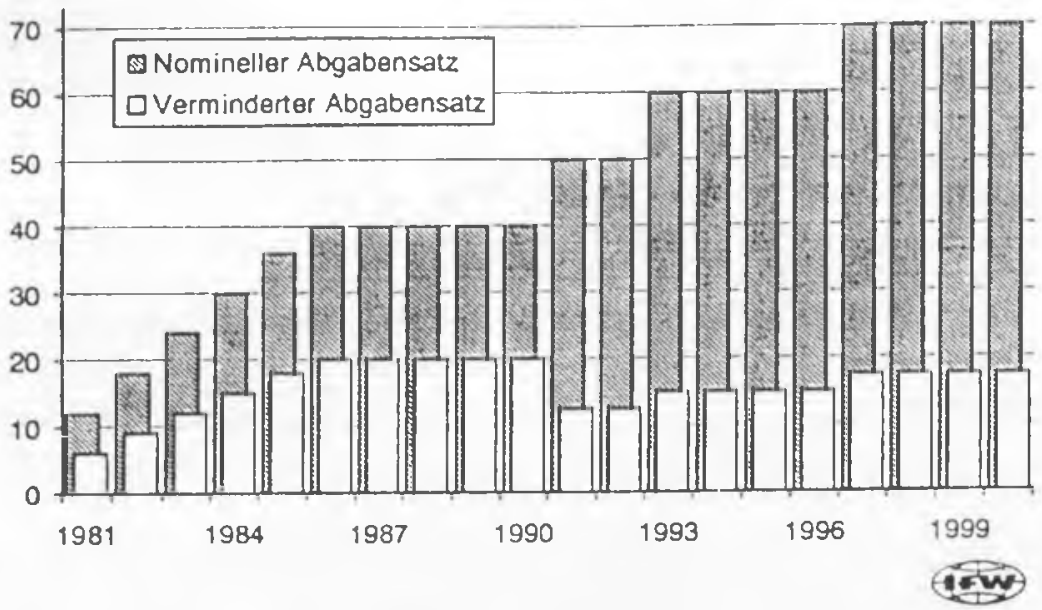

De duitse wet op de afvalwaterhefling is vanzelfsprekend niet representatief voor het milieuheffingenbeleid in andere landen. Hij illustreen wel hoe milieubeleidsmakers en betrokkenen (in de hoofdzaak publieke instanties - ook enkele privébedrijven - die rioolwaterzuiveringsinstallaties in bedrijf hebben) mettertijd overeenkomen, de werkelijke milieuheffing te verminderen als blijkt dat de milieukwaliteit van het aan het milieu (oppervlaktewater) geleverde product (afvalwater) toeneemt

Figur I laat zien dat rioolwaterzuiveringsinstallaties, die aan bepaalde - administraticfrechtelijk geregelde - milieukwaliteitseisen voldoen, van een gereduceerd tarief genieten Als men bedenkt dat de wetgeving ook nog toelaat dat investeringskosten van de afvalwaterhefling kunnen worden afgetrokken, worde duidelijk dat milieuheffingen inderdaad als een nexibel instrument voor milieubeleid worden beschouwd Milieubelastingen als instrument ter financiering van de algemene middelen zijn vanuit het oogpunt van de betrokkenen veel minder interessant 


\section{II.2 Tegenargumenten}

De argumenten tegen milieubelastingen van de industrie zijn zwaarwegend:

- dirigistisch: milieubelastingen hebben niets te maken met een flexibilisering van het milieubeleid. Belastingen zijn in werkelijkheid niets anders als pogingen van de overheid, beslag te leggen op het vermogen en het inkomen van de particuliere sector. Het milieubeleidsargument functioneert in deze context als willekeurig en nieuwsoortig. Vroegen waren rijtuigen of ramen grondslagen van belastingsinnovatieve wetgevers Vandang moet de zorg voor het milieu deze functie vervullen;

- ontsturend: milieubelastingen beroven de industrie van de financiële middelen die voor het industriële milieubeleid ter beschikking zouden kunnen worden gesteld. Het vertrouwen in de overheid, dat de opbrengsten van milieubelastingen milieugerecht worden besteed, bestaat op dit ogenblik niet;

- niet selectief: milieubelastingen houden geen rekening met de individuele technische en odernemingsspecifieke potentialen, milieuverbeteringen te realisieren;

- onproductief: milieubelastingen leiden tot een financiële „omweg“ van middelen via de belastingsdiensten. Milieuverbeteringen zijn daardoor niet te verwachten. De voordelen liggen bij de ambtenarij;

- niet geschikt om het beoogde milieudoel te bereiken. In deze context is zelfs sprake van een ecologische valstrik, als de milieubelasting tot een verschuiving van het milieuprobleem leidt. Het belangrijkste voorbeeld betreft de verplaatsing (relocatie) van bedrijven of economische activiteiten naar elders. Het milieuprobleem blij凡 onopgelost en er onstaat werkloosheid.

\section{II.3 Economische theorie}

Wat zegt de microeconomische theorie van de onderneming over al deze argumenten? In een eerste aanloop bekijken we twee modellen in het kader van een statische analyse: een model van mededinging en een model van (beperkte) marktbeheersing. Het verschil tussen beide modellen bestaat vooral hierin, dat mededingers door het mechanisme van de concurrentie gedwongen worden, tegen de geldende marktprijs te verkopen. Marktbeheersers kunnen differentiëren: zij zijn in staat sommige klanten tegen ecn hogere, andere tegen een lagere prijs te bedienen. Daardoor lukt het, een extra winst te boeken. Dat voordeel hebben mededingers niet. In dat opzicht zijn zij, zeker op de lange termijn, gedwongen, „slank" te produceren.

Met behulp van enkele grafieken kan worden verduidelijkt, hoe een milieuheffing het wel en wee van een bedrijf beïnloedt. Eerst komt het mededingingsmodel aan de orde. (Figuur 2 ). 
Figuur 2: Milicuhefringen in cen medelingingsmarkt
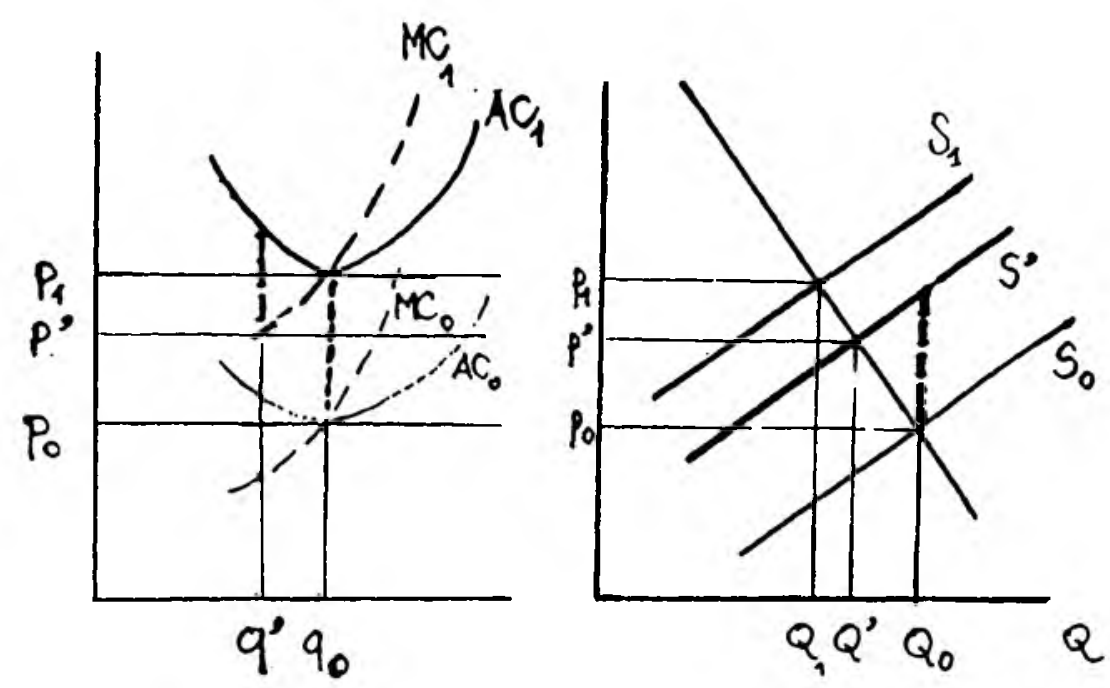

Rechts staat de markt afgebeeld, met behulp van vraag- en aanbodcurven. Oorspronkelijk is het marktevenwicht door de evenwichtsprijs $p_{0}$ en de evenwichtshoeveelheid $Q_{0}$ voorgesteld. Links is een onderneming afgebeeld. De medededingsvoorwaarden zorgen voor een "slanke" productie: de onderneming produccert tegen de laagste gemiddelde kosten en levert een hoeveelheid $q_{0}$ aan de markt, uiteraard tegen de prijs $p_{0}$. De kosten van de onderneming worden precies door de opbrengsten gedekt. "Slank" produceren betekent dat de gemiddelde kosten (de kosten per eenheid product) niet hoger en niet lager, maar precies gelijk zijn aan de prijs.

Dan kont de milieuheffing, die de prijs van $p_{0}$ naar $p_{l}$ verhoogt. De verticale stippellijn rechts verbeeldt de heffing. Het evenwicht in de onderneming wordt daardoor danig geschokt. De "slanke“ productiemethode - een gevoly van de concurrentie - laat nict toe dat de onderneming de milieuheffing uit een of andere reserve betaalt. Een dergelijke reserve is er gewoonweg niet. De enige oplossing bestaat erin, de milieuheffing in de prijs door te berekenen. Dat is overigens ook het geval voor de concurrentie.

Onze onderneming neemt een aanloop en verhoogt de prijs van $p_{0}$ naar p'. Meteen volgt de concurrentie. Rechts is het resultaat afgebeeld: de markt krimpt in van $Q_{0}$ naar $Q^{\prime}$. Dat 
inkrimpen is door de beleidsmakers gewild, omdat zo het nadelige milieueffect wordt verminderd.' Voor de onderneming is de situatie onhoudbaar. De kosten zijn door de milieuheffing gestegen. De gemiddelde kostenlijn $\mathrm{AC}_{0}$ is verticaal naar boven verplaatst $\left(A C_{1}\right)$ en wel ter waarde van de milieuheffing.

De inkrimping van de markt treft ook onze onderneming. We nemen aan dat de afzetbare hoeveelheid van $q_{0}$ naar $q^{\prime}$ afneemt. De gemiddelde kosten bedragen dan $A C_{l}$. Ze zijn duidelijk hoger dan de prijs $\mathrm{p}^{\prime}$ en de onderneming lijdt verlies. De andere ondernemingen staan voor soortgelijke problemen. Het gevolg is dat na de markt ook de branche inkrimpt. Welke onderneming dichtgaat kan het model niet voorspellen, ondat het ervan uitgaat dat alle ondernemingen in een concurrentiemarkt als het ware uitwisselbaar zijn. Het model voorspelt alleen dat er ondernemingen zijn die sluiten.

Aan het einde van de aanpassing gebeuren er twee dingen. De prijs wordt uitcindelijk op de oude prijs $p_{0}$ plus de milieuheffing vastgesteld $\left(p_{1}\right)$. De markt krimpt verder in tot het nieuwe marktevenwicht, waarbij een hoeveelheid $Q_{1}$ wordt verkocht en de overgebleven ondernemingen weer de oorspronkelijke hoeveelheid produceren (voor onze onderneming: $q_{0}$ ) tegen de laagste gemiddelde kosten, die overigens gelijk zijn aan de oorspronkelijke prijs $p_{0}$ plus de milieuheffing $\left(p_{1}\right)$

Resultaat:

- Door de milieuheffing zijn de markt en de branche ingekrompen;

- Het milicuprobleem (van de productie of van de consumptie) is afgezwakt;

- De overgebleven odernemingen produceren evenveel als voor de milieuhefring;

- De nieuwe prijs is gelijk aan de oude plus de milieuhefting;

- Welke ondernemingen het loodje moeten leggen en welke ondernemingen overleven kan niet a priori worden vastgesteld.

Beoordeling:

Wat vanuit het standpunt van een milieubeleidsmaker als een succes wordt gezien ist vanuit het standpunt van de branche een ramp. Een terugdringen van een milieuprobleem wordt met werkloosheid bekocht, tenzij elders nieuwe banen worden geschapen. De opbrengsten van de milieuheffing zouden daartoe zelfs kunnen worden gebruikt, bijvoorbeeld in het kader van een ecologische herstructurering van de economie. Maar de zorg van de betrokken branclie blijft bestaan.

Het kan natuurlijk anders, als we ervan uitgaan dat de wereld niet statisch, maar dynamisch is. Concreet betckent dit dat de milicuheffing (of haar aankondinging) een prikkel tot milieutechnische innovatic uitlokt. Onze onderneming stelt bijvoorbeeld vast (de concurrenten overigens ook) dat de productie ecologisch bezien eigenlijk niet "slank" verloopt. Het blijkt dat, onder meer, energiebesparingen mogelijk zijn en dat dure

Voor de uitcenzelting is lice nict zo belangrijk of lict milicuproblecm door de productic of de consumplic optrecdt. Hoofdzank is dat het afnecmt. 
rekeningen voor afvalverwerking worden betaald, terwijl dat afval nuttig verwerkt kan worden.

In een dergelijk geval kan de oorspronkelijke kostenlijn $A C_{0}$ naar beneden worden verschoven (niet in figuur 2 weergegeven) en de nieuwe prijs is dan niet gelijk aan de oude prijs plus de milieuheffing: het verschil is kleiner of zelfs nul. De milieuheffing wordt dan binnen de branche geabsorbeerd. Voortbordurend kunnen we stcllen dat de ecologische herstnucturering niet op macroeconomisch vlak maar op microeconomisch vlak, binnen de branche zelfs, plaats vindt.

Voor een branche die de "wet van de mededinging" als dagelijks brood kent biedt een dergelijk perspectief een uitkomst. Voor de beleidsmakers die het instrument van de milieubelasting willen gebruiken, levert dit voorbeeld een les: nilieubelastingen kunnen door het bedrijfsleven als ontrustzaaiers worden beschouwd als niet duidelijk is wie de winnaars en de verliezers zijn. Voor het milieu en voor de betrokken branche zijn ze dan een zegen als ze productieprocessen of producten belasten en tegelijkertijd milicuverbeterende innovaties binnen de betrokken branche uitlokken.

Een dergelijke aanpak vergt een specifieke bestudering van de mogelijkheden, zulke innovaties in de praktijk on te zetten. En als we dan zover zijn, rijst welhast vanzelf de vraag, of milieubelastingen het geschikte instrument zijn. Wie zich als onderneming en als milieubeleidsmaker zo intensief met het milieu-innovatie-potentiëel van bepaalde branches bezighoudt moet zich afvragen of een convenant niet evengoed functioneert en zelfs goedkoper werkt omdat de "omweg" via de belastingdienst niet hoeft te worden genomen.

Ik stap over naar model 2: de marktbeheerser. Een marktbeheerser controleert zijn eigen "markt" of marktaandecl. Het probleem van de verwerking van een milieuheffing kan daarom in een enkele figuur worden bestudeerd (figuur 3 ). 
Figuur 3: Milieuheffingen voor een marktbehcerser

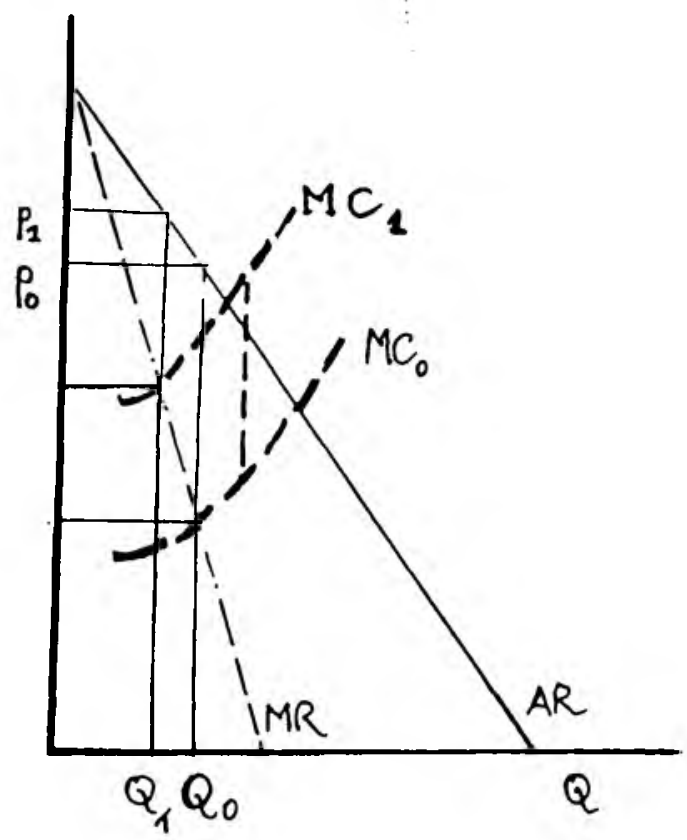

Marktbeheersers voeren een ander beleid dan mededingers: zij zijn in staat bepaalde klanten prijsconcessies te garanderen, die voor andere klanten niet gelden. Die betalen meer. Het klassieke model is het monopolie. In de praktijk komen monopolies haast niet voor. Wat voorkomt zijn verschillen in substitutiemogelijkheden: sommige klanten hebben grotere keuze of uitwijkmogelijkheden dan andere. Marktbeheersers putten dergelijke verschillen ten eigen bate uit. Strategische instrumenten zijn, onder andere, reclame en andere vormen van stimulering tot herhaald koopgedrag

Figuur 3 laat zien over welke mogelijkheden cen markibeheerser besclikt. Zijn „markt“ wordt door de lijn van gemiddelde opbrengsten AR weergegeven. Duidelijk wordt dat hogere gemiddelde opbrengsten (prijs per eenheid product) een geringere vraag uitlokken dan lagere gemiddelde opbrengsten. De strategie van een marktbeheerser leidt tot de volgende opzet: de werving van klanten met behulp van prijsconcessies gaat zolang door tot de extra kosten, die nodig zijn om aan deze vraag te voldoen nog net worden gedekt. De calculatie vindt dus niet - in tegenstelling tot de mededingers ${ }^{6}$ - op het vlak van gemiddelde kosten maar in de marge plaats. crenwiclit op lange termijn valt het resultaat daarann samen met een gemiddelde kostencalculering. 
Daarom is in figuur 3 ook de lijn van marginale opbrengsten afgebeeld (MR). Deze lijn schetst het verloop van de extra inkomsten die door prijsconcessies worden gerealiseerd. Het spreekt vanzelf dat - voor iedere hoevecheid - deze extra inkomsten (marginale inkomsten) lager uitvallen dan de gemiddelde opbrengsten. Een marktbeheerser bedrijft zijn beleid van prijsconcessies tot aan een optimum. Als de extra kosten voor de productie (afgebeeld door de marginale kostenlijn $\mathrm{MC}_{0}$ ) gelijk zijn aan de extra inkomsten (lijn $\mathrm{MR}$ ) is dat optimum bereikt. (In figuur 3: hoeveelheid $Q_{0}$.)

Door de milieubelasting wordt de marginale kostenlijn $\mathrm{MC}_{\mathrm{o}}$ verticaal naar boven verplaatst $\left(\mathrm{MC}_{1}\right)$. De marktbeheerser stelt vast dat zijn "markt" inkrimpt. Het nieuwe optimum impliceert een lagere hoeveelheid $Q_{1}$. De geniddelde prijsverandering kan op de AR-lijn worden afgelezen ( $p_{1}$ in vergelijking met $p_{0}$ ). Het verschil met de mededingingsbranche is duidelijk:

- Marktbeheersers zijn in staat een milieubelasting binnen bepaalde grenzen te absorberen;

- De gemiddelde prijs na de milieubelasting is geringer als de oude prijs plus milieuheffing;

- De marktbeheerser wordt tot inkrimping gedwongen maar zijn overleven is niet bedreigd.

Ook bij dit model kan worden verondersteld dat de milieuheffing een dynamisch effect uitlokt: de $\mathrm{MC}_{0}$-lijn wordt dan naar beneden verschoven en de ecologische herstructurering vindt binnen de betrokken onderneming plaats. Analoog kan dan de vraag worden gesteld, of een milieubelasting als milieubeleidsinstrument eigenlijk duurder uitkomt dan een milieuconvenant.

Resultaat:

Een microeconomische beschouwing van de werking van milieubelastingen leidt tot de voorlopige conclusie dat de voordelen tegen bepaalde nadelen moeten worden afgewogen. Microeconomisch bezien hebben milieubelastingen een social aanvaardbare milieuverbeterende werking als een milieuinnovatie met kostenbesparingen binnen de betrokken branche wordt gerealiseerd.

Als deze ecologische verbetering alleen via een afbouw van werkgelegenheid in de betrokken branche en een toename van werkgelegenheid elders kan worden bereikt, ontstaan er aanpassings- en overgangseffecten. Die kunnen worden vermeden als de ecologische herstructurering binnen de betrokken branche wordt gerealiseerd. Concreet volgt daaruit dat milieubelastingen in dergelijke gevallen net zo goed door milieuconvenanten kunnen worden vervangen. 


\section{De praktijk}

\section{III.1 Inleiding}

Sinds vele jaren verschijnen met grote regelmaat overzichten over de praktijk van milieuheffingen en milieubelastingen. De OECD is de pionier op dit gebied. ${ }^{7}$ De overzichten van de OECD hebben ook de inspiratie opgeleverd om recepten over het gebruik van deze instrumenten voor te stellen. Ten behoeve van de beleidsmakers worden tips en goede raad gegeven, wat met deze instrumenten kan worden bereikt en hoe ze effectief kunnen worden gebruikt. Vanuit een beleidsstandpunt kunnen twee criteria worden genoend: ecologische effectiviteit en economische efficiency.

In de laatste jaren is een derde criterium opgerukt: de belastingsdruk is te hoog. Voor Duitsland geldt in 1996 dat 6 Juni als zogenaamde pay day werd vastgesteld. Tot en met die dag werkte eenieder in dat land "voor de overheid". Het beslag dat de overheid op het inkomen van de privésector legt betreft dus een tijdsbestek van bijna een half jaar. Daaruit volgt dat milieuheffingen en milieubelastingen alleen maar dan een kans maken, als ze andere heffingen en belastingen vervangen. Dat is precies de doelstelling van de ecologische belastinghervorming. Die gaat ervan uit dat de huidige belastinggrondslagen het milieu schade berokkenen of tenminste nict bevorderen, terwijl er andere belastinggrondslagen bestaan, die door het huidige belastingbeleid niet of te weinig worden benut en voor het milieu voordelen hebben. De hervorming dient zodanig te worden doorgevoerd dat de inkomsten gelijk blijven.

Met deze confrontatie van het bestaande en een ander, ecologisch effectief, belastingbeleid kom ik tot een belangrijke kernvraag:

\section{Is het huidige belastingbeleid milieuschadelijk?}

Merkwaardig genoeg is deze vraag niet of weinig onderzocht. De economen hebben in dat verband de theorie van de externe kosten ontwikkeld. Die zegt dat de marktprijs voor een product niet in alle omstandigheden de totale gemiddelde kosten van de productie en distributie omvat. Er onstaat bijvoorbceld schade aan het milieu, die nict door de producent en de handel worden vergoed en daarom de rentabilitcit van andere economische activiteiten negatief beïnvloedt. Deze theorie van de extcrne effecten ligt dan ook aan de grondslag van de opstelling van het basisprincipe dat de vervuiler betaalt.

7

OECD:

- Economic Instrumenls for Environunental Prolection, 1989

- Environmental Policy: How to Apply Economic Instruments? 1991

- Taxation and the Environment; Complementary Policics, 1993

- Managing the Environment: The Rolc of Economic Instnunents, 1994 
Daaruit volgt dan de raad vanwege de economen, het marktmechanisme te corrigeren, als niet alle externe kosten in de marktprijs zijn vervat. Een en ander leidt tot belastingen en heffingen die door bepaalde gebruikers van, bijvoorbeeld milieuschadelijke ressourcen, moeten worden betaald. Zoals ik in de inleiding al stelde is de omvang van de ecologische belastingen mar beperkt. Onze belastingsstelsels bestaan in de hoofdzaak uit inkomstenbelastingen en de BTW en enkele belangrijke productbelastingen zoals de belasting op minerale olies.

De vraag kan worden gesteld of, en in welke mate, de inkomstenbelasting en de BTW milieuschadelijk zijn en derhalve in het kader van een duurzame ontwikkeling dienen te worden herzien. I $k$ ga op deze vraag hier niet verder in. I $k$ wil in het volgende aan de hand van enkele voorbeelden omtrent milieuvervuilende activiteiten illustreren dat ecologische belastingen vooral met betrekking tot hun doelgerichte werking in de praktijk niet altijd gunstig worden beoordeeld. Pas als dergelijke concrete vraagstukken ten voordele van de ecologische belastingen kunnen worden opgelost kan naar mijn gevoel de ecologisering van de inkomstenbelasting of van de BTW alsnog worden aangepakt.

\section{III.2 Voorbeelden uit de praktijk}

Een recent gepubliceerde toepassing van de theorie van de externe effecten heef te maken met de kosten van het verkeer, en dan meer in het bijzonder, van het wegverkeer. ${ }^{8}$ De externe effecten van het huidige wegverkeer zijn enorm. In het rapport wordt vastgesteld dat vooral het wegverkeer externe kosten in miljardenbedragen veroorzaakt, door verloren tijd in files, milieuschade en "reparatie" van schade aan de gezondheid, die niet door de gebruikers van het wegvervoer worden terugbetaald. Een en ander volgt uit het feit dat het wegverkeer vele, talloze, gebruikers kent. Tijdens een file komt niemand op het idee van een andere weggebruiker schadevergoeding ten gevolge van de opgelopen vertraging te vorderen. Belangrijke redenen kunnen worden opgesomd:

- Elke weggebruiker is tegelijkertijd veroorzaker en slachtofter van een file;

- Het is niet duidelijk welke weggebruiker voor de "vertragingskosten" van een wel bepaalde andere weggebruiker oorzakelijk verantwoordelijk is;

- Een objectieve vaststelling van de „vertragingskosten“ is vaak niet mogelijk. Wat zijn de kosten van een verlate of gemiste afspraak?

Vergelijkbare redenen kunnen in verband met de milieukosten worden opgesomd. Met betrekking tot de gezondheidsschade en -reparatiekosten geldt een analoog argument: in hoeverre geldt het principe: is de dader aansprakelijk? In hoeverre geldt het principe: is het slachtoffer aansprakelijk? 
Ik kom terug op mijn eerste kernvraag: kan een ecologisch gericht belastingsstelsel het geschetste probleem beter oplossen en ervoor zorgen dat de milieukosten geïnternaliseerd worden? Het voorbeeld van het wegverkeer levert enig inzicht. In alle lidstaten van de Europese Unie en ook elders bestaat er een belasting op minerale brandstoffen op koolwaterstofbasis (benzine, diesel). Deze belasting levert aanzienlijke inkomsten voor de overheid op. In Europa is deze belasting zeer hoog: in de praktijk bedraagt zij $65 \%$ (Luxemburg) tot $79 \%$ (Frankrijk) van de prijs (Nederland: 74\%). Tabel 2 geeft een overzicht.

Tabel 2: Belasting van loodvrije benzine in procenten van de raffinaderijprijs

\begin{tabular}{|l|c|}
\hline Land & percent \\
\hline Frankrijk & 78,8 \\
\hline Duitsland & 76,0 \\
\hline Nederland & 74,1 \\
\hline Zweden & 72,2 \\
\hline Finland & 71,8 \\
\hline België & 71,6 \\
\hline Griekenland & 71,4 \\
\hline Noorwegen & 71,3 \\
\hline Portugal & 70,3 \\
\hline Verenigd Koninkrijk & 70,2 \\
\hline Zwitserland & 69,6 \\
\hline Denemarken & 68,0 \\
\hline Zrland & 66,0 \\
\hline Spanje & 65,5 \\
\hline Luxemburg & 65,0 \\
\hline Oostenrijk & 63,6 \\
\hline
\end{tabular}


Toch blijkt dat de benzinebelastingopbrengst in verglijking met de externe kosten van het wegverkeer gering is. De duitse wetenschapsminister Jürgen Rüttgers deelde onlangs de deelnemers aan een conferentie van het Deutsche Verkehrsforum in Bonn ${ }^{10}$ mee:

„Die deutsche Industrie hat errechnet, daß durch Verkehrsbehinderungen und Staus pro Jahr Arbeitszeit, Kraftstoff und Kapital im Wert von rund 200 Milliarden Mark in Deutschland vergeudet werden."

Hij had het dan alleen over files en niet over de andere cxterne effecten voor het milieu en de gezondheid. De huidige opbrengst van de belasting op minerale olie bedraagt ongeveer 65,5 miljarden DM. Een simpele berekening leert dat externe kosten van 200 miljarden DM een belastingvoet op minerale olie vergt die 232 procent van de raffinaderijprijs bedraagt. Een zo hoge belastingvoet staat in het verdacht, vanuit belastingrechtelijk oogpunt als „Erdrosselungssteuer" te kunnen worden opgevat en derhalve de vrije burgerrechten op ontoelaatbare wijze te beperken. Ik kan op dit bezwaar van juridische zijde niet verder ingaan.

Vanuit een meer economisch standpunt, dat uiteraard een daling van de vraag naar wegverkeer voorspelt als de belastingvoet op de minerale olie een dergelijke sprong makt, kan de vraag worden gesteld hoe groot het écart tussen producentenprijs en consumentenprijs - door de belasting veroorzaakt - mag zijn om de werking van het marktmechanisme nog te behouden. Als het belastingbeleid van de overheid de dominante factor voor de feitelijke werking van de markt wordt, heeft het particulier initiatief geen vat meer op de markt. Dan willen ondernemers niet meer meespelen. Deze situatie wordt met de dreigende terminus technicus „ecodictatuur" omschreven. Zij herinnert aan het argument van het bedrijfsleven, dat ecologische belastingen als dirigistisch worden afgewezen.

\section{III.3 Voorbeeld 2: energiebeleid}

De grootste globale bedreiging voor het milieu en voor de toekomst van de mensheid is de langzame en gestadige toename van de gemiddelde luchttemperatuur op lange termijn: het broeikaseffect. Ik wil hier niet de geschiedenis van de ontdekking van dit verschijnsel herhalen en mij tot het huidige beleid van de lidstaten van de Europese Unie beperku.

De doelstelling bestaat erin, de emissies van $\mathrm{CO}_{2}$ in 2000 tot die van het jaar 1990 terug te brengen. In een recent rapport van de Europese Commisie" wordt ernstig betwijfeld dat deze doelstelling wordt bereikt. Tabel 3 levert - in telegramstijl - een overzicht van de beleidsverwachtingen van de lidstaten.

11 European Conmission: Second evaluation of national programmes under the monitoring mechanism of Community $\mathrm{CO}_{2}$ and other grcenhousc gas cmissions: Progress touards the Community $\mathrm{CO}_{2}$ target stibilisation. COM (96) 91. Jinal, 14.03.1996. 
Tabel 3: $\mathrm{CO}_{2}$-emissicbeleid van de lidstaten van de Europese Unie

\begin{tabular}{|c|c|}
\hline Lidstaat & Omschrijving \\
\hline België & Doel wordt niet bereikt zonder $\mathrm{CO}_{2}$-belasting. \\
\hline Denemarken & $\begin{array}{l}\text { Doel wordt alleen bereikt als specifieke voorwaarden worden } \\
\text { vervuld (vermindering van electrische verwarming en strengere } \\
\text { normen voor energie-efficiency. }\end{array}$ \\
\hline Duitsland & Doel (2005) wordt zonder $\mathrm{CO}_{2}$-belasting niet bereikt. \\
\hline Finland & Doel wordt nict bereikt $(+18 \%$ in 2000$)$ \\
\hline Frankrijk & Doel wordt niet bereikt (minstens $+7 \%$ in 2000). \\
\hline Griekenland & Toename van emissies $(+12 \%$ tot $+18 \%)$ \\
\hline Ierland & $\begin{array}{l}\text { Verwachte toename van emissies }(+20 \%) \text { wordt niet overschreden } \\
\text { als energiebesparingsmaatregelen functioneren. }\end{array}$ \\
\hline Italië & Doel wordt niet bereikt $(+1 \%-+5 \%$ in 2000$)$. \\
\hline Luxemburg & $\begin{array}{l}\text { Doel wordt bereikt (-33\% in } 2000 \text { door herstructurering van de } \\
\text { staalindustrie). }\end{array}$ \\
\hline Nederland & $\begin{array}{l}\text { Doel kan worden bereikt als alle matregelen, inclusief } \mathrm{CO}_{2} \text {-belasting } \\
\text { voor kleinverbruikers en convenanten met grootverbruikers worden } \\
\text { genomen. }\end{array}$ \\
\hline Oostenrijk & $\begin{array}{l}\text { Doel wordt alleen bereikt als de maatregelen voor 1994-1998 } \\
\text { onmiddellijk worden genomen. }\end{array}$ \\
\hline Portugal & $\begin{array}{l}\text { Verwachte toename }(+40 \% \text { in } 2000) \text { is onzeker (naar boven of naar } \\
\text { beneden). }\end{array}$ \\
\hline Spanje & $\begin{array}{l}\text { Doel wordt bereikt als correcties vor de jaartemperatuur van } 1990 \\
\text { worden geaccepteerd. }\end{array}$ \\
\hline Verenigd Koninkrijk & $\begin{array}{l}\text { Doel wordt bereikt door een vervanging van steenkool door aardgas } \\
\text { en niet door energiebesparing. }\end{array}$ \\
\hline Zweden & Na correctie voor de temperatuur van 1990 wordt het doel bereikt. . \\
\hline
\end{tabular}

Bron: Samenvalting op basis van hel rappon COM (96) 91 van de Europese Commissic.

De Europese Commissie heeft al in 1993 een voorstel voor een europese $\mathrm{CO}_{2^{-}}$en energiebelasting naar de Ministerraad gestuurd. Een lijvige wetenschappelijke studie naar de 
ecologische en economische effecten van een dergelijke belasting ging daaraan vooraf. ${ }^{12}$ Het voorstel kende geen succes en werd in afgezwakte vorm in 1995 geamendeerd. ${ }^{13}$ Een en ander heeft te maken met het feit dat de lidstaten hun energiebeleid (dat in belangrijke mate de uitworp van $\mathrm{CO}_{2}$ bepaalt) grotendeels in eigen beheer willen behouden

In het Verdrag over de Europese Unie en de Europese Gemeenschap (Verdrag van Maastricht) is vastgesteld (in het Verdrag over de oprichting van de Europese Gemeenschap) dat de Gemeenschap maatregelen met betrekking tot het energiebeleid kan nemen (Artikel $3 \mathrm{t}$ ). In de eerste verklaring van de slotacte (concluding act) is vastgesteld dat de regeringen van de lidstaten naar aanleiding van de herziening van het Verdrag in 1996 deze bepaling zullen onderzoeken. Uiteraard is de Europese Commissie de mening toegedaan dat een en ander blijft zoals in Maastricht was besloten.

Een aantal lidstaten, waaronder Nederland, hebben onafhankelijk van deze ontwikkelingen een nationale $\mathrm{CO}_{2}$ - en energiebelasting ingevoerd. De praktijk laat zien dat deze nationale regelingen complex zijn. $\mathrm{Er}$ is geenszins sprake van een belastingvoet die voor alle energieverbruikers dezelfde is. De nationale wetgever blijkt eensdecls met de mogelijkheden tot energiebesparing van diverse groepen of categorièn van energieverbruikers en andersdeels de internationale concurrentieposities van deze categoriën rekening te houden. Deze dubbele visie leidt ertoe dat, bijvoorbeeld in Nederland, alleen de zogenaamde kleine energieverbruikers nu meer belasting betalen. Is deze regeling dan sociaal bedenkelijk? Hoe kan een dergelijk beleid worden verduidelijkt?

De situatie in Duitsland kan voor opheldering zorgen. In de vorige legislatuurperiode werd door de Bondsdag een zogenaamde "Enquete-Kommission" geïnstalleerd om een onderzoek in te stellen naar de grondslagen voor het toekomstige milieubeleid. In feite was deze commissie belast met de vraag beleidsopties voor de implementatie van de UNCEDconferentie in Rio de Janeiro (1992) voor Duitsland vast te stellen. Het probleem van het broeikaseffect stond op de agenda. Die commissie heef dat probleem pragnatisch aangepakt en het $\mathrm{CO}_{2}$-besparingspotentiëel van diverse categoriën energieverbruikers onderzocht. Het resultaat van deze enquete is in Tabel 4 weergegeven.

Eurpean Commission: The economics of limiting $\mathrm{CO}_{2}$ entissions, European Economy; Special edition No 1, Brussels, Luxemburg, 1992.

European Commission: Amended proposal for a directive of alic Council on the introduction of a tax on $\mathrm{CO}_{2}$ cmissions and encrgy, $\mathrm{COM}(05)$ 172. final. 
Tabel 4: $\mathrm{CO}_{2}$-besparingspotentiëel tot 2005 van verscheidene energieverbruikscategoriën in Duitsland

\begin{tabular}{|l|c|c|}
\hline \multicolumn{1}{|c|}{ Categorie } & miljoen ton & $\%$ \\
\hline privésector & 64 & 39,6 \\
\hline energiesector & 55 & 33,6 \\
\hline industrie & 16 & 9,8 \\
\hline verkeer & 15 & 8,5 \\
\hline kleinverbruikers & 14 & 8,5 \\
\hline totaal & 164 & 100 \\
\hline
\end{tabular}

Bron: Bundesministenum für Umwclt, Naturschutz und Reaktorsichcrhcit

Uit dit overzicht blijkt dat het grootste potentiëel voor $\mathrm{CO}_{2}$-besparing niet bij de industrie, maar bij de particuliere huishoudens gelocaliseerd is. Op de tweede plaats volgt de energiesector (openbare electriciteitsnutsbedrijven en raffinaderijen). Beide „sectoren“ zijn goed voor driekwart van het totale $\mathrm{CO}_{2}$-besparingspotentiëel. De vraag rijst of en hoe een energiebelasting ertoe aanzet dat potentiëel in de praktijk om te zetten.

Economen onderscheiden tussen prijseffect en inkomenseffect. Hoe hoger het inkomen van consumenten, hoe geringer het aandeel van dat inkomen dat voor energie wordt besteed. Statistische data voor Duitsland leveren het volgende overzicht

Tabel 5: Aandeel van de bestedingen voor energie naar inkomensklassen (1993)

\begin{tabular}{|l|l|c|c|}
\hline \multicolumn{1}{|c|}{ Klasse } & \multicolumn{1}{|c|}{ Omschrijving } & Inkomen (DM) & Aandeel (\%) \\
\hline "arm" & $\begin{array}{l}\text { gepensioneerd, werkloos, met } \\
\text { uitkering }\end{array}$ & 2535 & 6,2 \\
\hline "gemiddeld inkomen" & werknemersfunctie & 6200 & 3,9 \\
\hline "hoog inkomen" & leidinggevende functie & 8450 & 2,9 \\
\hline
\end{tabular}

Bron: Institut der deutschen Wirschaft. 1995 
Bij een verhoging van de energieprijs met $10 \%$ neemt het aandeel van de bestedingen voor energie toe met respectievelijk $0,6 \%, 0,4 \%$ en $0,3 \%$. Dat is bitter weinig en bovendien regressief. Daaruit volgt dat het $\mathrm{CO}_{2}$-spaarpotentiëel van de privésector alleen dan daadwerkelijk beinvloedt als het aandeel van het besteedbaar inkomen voor energie onder invloed van een energiebelasting in belangrijke mate wordt verhoogd.

Het milieuverbeterende succes van een dergelijke, hoge energiebelasting kan natuurlijk worden verhoogd als de inkomsten in de vorm van subsidies voor energiebesparende maatregelen in de privésector worden besteed. Vooral huiseigenaars zouden daarvan kunnen profiteren, als zulke maatregelen binnen hun bereik vallen: dubbel of zelfs drievoudig vensterglas, isolatie en energiebesparende huishoudtoestellen. Huurdoers hebben minder mogelijkheden, tenzij het eigendomsrecht hun toelaat, dezelfde maatregelen met of zonder toestemming van de eigenaren te nemen. Arme inkomensklassen ervaren alleen dan een prikkel als zij zelf hun energickosten dragen. Als deze kosten door de sociale welzijnsadministraties van de gemeenten worden gedragen, valt deze prikkel weg.

$\mathrm{Nu}$ zou het kunnen dat een - zelfs bescheidene - energiebelasting het $\mathrm{CO}_{2}$-besparingspotentiëel van de electriciteitsbedrijven beinvloedt en entoe leidt dat deze bedrijven ertoe worden aangezet, het bestaande warmteverlies te verminderen. Daardoor verhoogt hun rendement en neemt het ecologisch nadelige effect van hun activiteit af. In de praktijk wordt deze conclusie afgezwakt door het feit dat de electriciteitsbedrijven als marktbeheersers kunnen worden beschouwd en derhalve over speelnumten beschikken, de energiebelasting ten dele af te wentelen. Daardoor blijft de prikkel, de efficiency van de omzetting van primaire energiebronnen in electriciteit te verbeteren, beperkt.

Resultaat:

Een ecologische belasting op energie met als doelstelling een $\mathrm{CO}_{2}$-besparing dient welhaast onvermijdelijk de privésector en de energienutsbedrijven te treffen omdat deze sectoren over het grootste $\mathrm{CO}_{2}$-besparingspotentiëel beschikken. De effectiviteit van een energiebelasting in de privésector hangt in belangrijke mate van het inkomenseffect af. Dat laatste moet hoog zijn en werkt dan regressief. De nutsbedrijven kunnen de energiebelasting ten dele afwentelen.

\section{III.3 Voorbeeld 3: technologische ontwikkelingen}

Een bijzonder ecologisch-economisch conflict dat al in de nabije toekomst - vooreerst pragmatisch en later fundamenteel - dient te worden opgelost, heef te maken met de toekomst van de mobiliteit en, met name, van het individuele personenvervoer. In de mate waarin de industrie zijn procesmatige bijdrage aan de milieuschade vermindert, neemt het aandeel van de particuliere sector toe. Het milieuprobleem verkrijgt een nieuwe dimensie: de grote, identificeerbare, bronnen van milieuvervuiling binnen het bedrijfsleven worden stilaan „drooggelegd“. De talrijke, diffuse bronnen van milieuvervuiling binnen de particuliere sector worden belangrijker. 
Vanuit een ecologisch belastingperspectief bestaat de juiste oplossing in een milieubelasting op de emissies van deze bronnen. Als voorbeelden van belastinggrondslagen kunnen worden benoemd:

- emissies van het privéwegverkeer,

- verpakkingsafval;

- afvalwater;

- afgedankte duurzame consumptiegoederen (televisies, koelkasten, keukenfornuizen, kleding, computers, tapijten, sloopafval, etc.);

- klein chemisch afval;

- koolwaterstoffen in oplosmiddelen;

- emissies van vrijetijds-consumptie (toerisme);

- emissies van gezondheidsmatig bedenkelijke producten (tabakproducten, mobiele telefoontoestellen (?));

- storingen van het grondwaterbeheer door bebouwing of betonering van percelen; ${ }^{14}$

- luchtvervuilende stoffen in uitlaatgassen van cv-stookketels;

- verstoring van de rust door geluidshinder.

Deze lijst is niet volledig en geeft alleen maar een indicatief overzicht van de talloze consumptieve activiteiten die onder bepaalde omstandigheden een nadelig effect voor het milieu impliceren. Met betrekking tot de meeste van deze consumptie activiteiten (als uitzondering zij verwezen naar de afvalwaterheffing) bestaan er geen ecologische belastingen. Daaruit volgt de tentatieve conclusie dat het huidige belastingsstelsel - in het bijzonder met betrekking tot consumptieve activiteiten - inderdaad geen rekening houdt met de potentiële milieuschadelijke gevolgen van dergelijke activiteiten. Volgt daaruit dat het huidige belastingstelsel als milieuschadelijk dient te worden beschouwd?

In principe luidt een voorlopig antwoord: ja, al was het maar omdat deze consumptieve activiteiten wel belast worden, maar niet met betrekking tot hun ecologische effecten. Tot op de huidige dag is er geen enkele aanduiding dat de typische belastingvorm van consumptieve activiteiten, met name de BTW, ecologisch nadelige effecten tracht te beperken. De vraag rijst of er in deze context een mogelijkheid bestaat, de BTW door een EBTW, een ecologische BTW te vervangen. Het antwoord op deze vraag zou kunnen luiden dat het huidige BTW-stelsel wordt opgesplitst in een normaal BTW-stelsel en een „groen“ BTW-stelsel; dat laatste is dan van toepassing op, noch te bepalen, lage-emissieproducten. 
Met dit antwoord op deze vraag kom ik terug op het tweede voorbeld, dat de relatie tussen een ecologisch geïnspireerde energiebelasting en het $\mathrm{CO}_{2}$-spaarpotentiëel van de diverse economische sectoren beschreef. In de praktijk blijkt dat een preciese analyse van de belastinggrondslag en van de ecologische effecten van een bepaalde belasting noodzakelijk is. Bekijken we in deze context het vraagstuk van de mobiliteit en meer bepaald van het wegverkeer. Als we ervan uitgaan dat de huidige ontwikkeling van het wegverkeer hoegenaamd niets of weinig te maken heet met sustainable development kunnen we ons afvragen hoe dit probleem dient te worden opgelost.

Economen zijn vlug gencigd om ecologische belastingen voor te stellen. Hun success story in dat verband heeft vooral te maken met de gedifferentièerde belasting voor loodhoudende en loodvrije benzine. De reactie van het bedrijfsleven en van de particuliere weggebruikers kwam snel: loodvrije benzine is nu overal verkrijgbaar. ${ }^{15}$

Daarnaast blijf het probleem van de stimulering van de technische ontwikkeling in de richting van een lager energieverbruik en een vermindering van het milieuprobleem van de afvalverwerking van afgedankte voertuigen. Een ander vraagstuk dat een veel verdergaande betekenis heeft dan een vervanging van loodhoudende door loodvrije benzine of een milieuconforme verwerking van afgedankte voertuigen, heeft te maken met een milieuconforme mobiliteitsteclnologie.

Daarmee zijn we bij de kern van de toekomstige mobiliteit in de zin van sustainable development: kan de huidige technologie op basis van ottomotoren en dieselmotoren worden verbeterd en daarmee de doelstelling van de duurzame ontwikkeling worden bereikt? Dat zou dan, bijvoorbeeld, betekenen dat een ontkoppeling van wegverkeer en $\mathrm{CO}_{2}$-emissies door energiebesparende aandrijflechnieken plaats vindt. Een decloplossing bestaat in het gebruik van aardgas

Mocht een dergelijke ontkoppeling met een verijinde teclınologie op de huidige basis niet mogelijk zijn, dan is een grotere omschakeling nodig. Een oplossing ligt in de ontwikkeling van electrisch aangedreven voertuigen op basis van brandstofcellen. Die kunnen electriciteit uit waterstof produceren. Daanuit volgt dan de noodzaak om het gehele net van pompstations aan te passen. Een alternatief bestaat erin, de waterst of in de voertuigen zelf te produceren. Dat kan met beliulp van methanol, dat door huidige pompstations kan worden verwerkt, via een zogenaande reformer. Het gehele proces - enigzins complex, dat wel - veroorzaakt minstens $40 \%$ minder $\mathrm{CO}_{2}$-emissies. Vanuit deze laatste optiek lijkt de waterstoftechniek ons korter bij de doelstelling van een duurzame ontwikkeling te brengen dan een verbetering van de huidige aandrijftechniek.

Het economische instrument dat deze technologische innovatic zou moeten inluiden is een belasting op de $\mathrm{CO}_{2}$-emissies van het wegvervoer. Meetkosten verhinderen deze oplossing, maar omdat het koolstofgehalte van alle koolwaterstofhoudende brandstoffen kan worden bepaald, kan de $\mathrm{CO}_{2}$-belasting door een $\mathrm{C}$-belasting op vloeibare brandstoffen voor het kennen. Zie bijvoorbeeld Hongarije. (Bron: Informationen 1995, Ungarn. Hungarian Tourist Board). 
wegvervoer worden vervangen. Daarmee zijn we terug bij onze uiteenzetting van de economische theorie (II.3). Die voorspelt in de eerste plaats een afname van de $\mathrm{CO}_{2}$ emissies door een vermindering van het wegvervoer, en in de tweede plaats, als dynamische veranderingen mogelijk zijn, een technologische aanpassing. Maar als de eigenlijke doelstelling erin bestaat, de techniek van de brandstofcellen voor het wegvervoer gereed te maken, lijkt een omweg via de autorijders als $\mathrm{CO}_{2}$-belastingbetalers weinig effectief. ${ }^{16}$ In een dergelijk geval geniet een administratiefrechtelijk bepaalde doelstelling de voorkeur. Een convenant ter implementatie dat de betrokkenen integreert, verantwoordelijkheden en tijdsbestekken vastlegt en tussentijdse evaluaties voorschrijft kan goede diensten leveren.

\section{Resultaat:}

- Ecologische belastingen die tot doel hebben, bepaalde technologiën te introduceren zijn vooral dan geschikt als deze technologiën het stadium van de innovatie (= overname door de markt) hebben bereikt. De ecologische belasting leven een prikkel tot overstap op de nieuwe technologiën en functioneert als een instrument voor de opening van de markt.

- Als de betrokken technologiën nog moeten worden ontwikkeld is het signaal van een ecologische belasting op zichzelf beschouwd onduidelijk. Als inderdaad door de beleidsmakers verwacht wordt dat daardoor nieuwe technologiën ontwikkeld worden kan ter vereenvoudiging net zo goed een administratiefrechtelijke regeling worden ingevoerd. Het betrokken milicuprobleem (de speurtocht naar een ecologisch duurzame technologie voor het wegvervoer) wordt dan onderwerp van het technologicbeleid en niet van het fiscaal beleid.

\section{Voortzetting van een vernieuwd debat}

Zijn milieubelastingen alleen maar interessant voor een academisch debat? De oorspronkelijke euforie omtrent de vervanging van administratief milieurecht door milieufiscaalrecltt lijkt te zijn verdwenen. Concrete voorbeelden uit de praktijk laten de volgende conclusies toe:

- Ecologische belastingen hebben een sturende werking met betrekking tot de overstap naar nieuwe, milieuverbeterende technologiën. Een belangrijke voorwaarde die moet worden vervuld bestaat erin, dat deze nicuwe technologiën op het tijdstip van de invoering van de milieubelastingen ter beschikking staan.

- Ecologische belastingen werken, zoals alle belastingen, marktontwrichtend. Het heeft weinig zin, milieubelastingsvoeten op zo hoog niveau vast te leggen dat het 
milieubelastingbeleid het marktgebeuren geheel domineert. In ecn dergelijke situatie haakt het bedrijfsleven af.

- Bescheiden milieubelastingen zijn weinig effectief in de ecologische zin. Terwijl milieubeleidsmakers het erover eens zijn dat deze conclusie juist is. blijf het risico van een marktontwrichting en - eventueel - regressieve gevolgen, als de betrokken milieubelastingvoeten drastisch worden verhoogd.

- Ecologische belastingen impliceren een „omweg" via de fiscus met betrekking tot de beoogde doelstelling. Zowel met betrekking tot de belastingbetalers als ook tot het reële sturende effect van een milieubelasting dient voor transparantie te worden gezorgd: voor alle betrokkenen moet een waarborg kunnen worden gegeven dat door de fiscale omweg het beoogde doel wordt bereikt.

- Ecologische belastingen concurreren met andere milieubeleidsinstrumenten: enerzijds met administratief rechtelijke instrumenten en anderzijds met - nieuwsoortige - vrijwillige instrumenten zoals convenanten. De keuze voor milieubelastingen wordt derhalve niet alleen bepaald door een kosten-baten-analyse van milieubelastingen maar ook door een afweging van de voorkeur voor milieubelastingen in vergelijking met andere milieubcleidsinstrumenten.

Hoe dient een zinvol debat omtrent de nilieubetcrende effecten van milieubelastingen in de toekomst te worden voortgezet? Alleen al door deze formulering ga ik ervan uit dat milieubelastingen ook in de tockomst effecticf, ten bate van het milieu, kunnen worden gebruikt. Het lijkt $\mathrm{mij}$ in dat verband wenselijk en nuttig dat economen, die milieubelastingen en soortgelijke fiscale milieuinstrumenten als superieure maatregelen opvatten, in de toekomst in grotere mate met de practische mogelijkheden rekening houden.

In de eerste plaats dient een onderscheid te worden gemaakt tussen fiscale doeleinden en een milieuverbeterend sturend effect. Als een fiscale doelstelling op de voorgrond staat, wordt de belastingdruk op de particuliere sector verzwaard, tenzij andere belastingen worden verlaagd. In dat geval onstaat er een verdelingsconflict waarvoor een oplossing dient te worden gezocht. Er is dan sprake van een winners and losers situatie, die, uiteindelijk, op het politieke vlak moet worden uitgevochten. Economen kunnen in een dergelijke situatie hooguit advies uitbrengen omtrent de uitkomsten voor de wirnaars en de verliezers.

Staat een milieusturend effect op de voorgrond, liggen de zaken anders, omdat - vanuit de beoogde milieudoclstelling - een milieubelasting ook dan als een succes kan worden beshouwd als de opbrengst gering of zelfs afwezig is.. De sturende werking van een dergelijke milieubelasting impliceert in dat geval een verregaande of zelfs volledige vervanging van een milieuschadelijke door een milieuvriendelijke activiteit. De taak van de economen bestaat er dan in, in samenwerking met andere disciplines, strategiën uit te werken, die een overstap naar de milieuverbeterende activiteit veroorloven, zonder of met minimale herverdelingsconflicten. 
Darom is het in de tweede plaats belangrijk, het onderzoek naar de ecologische functionaliteit van milieubelastingen te vernieuwen. Het heeft weinig zin, een resultaat dat eigenlijk van te voren is vast gelegd of tenminste beoogd - namelijk, dat milieubelastingen het ecologische neusje van de zalm zijn - door middel van economische modellen te ondersteunen en uiteindelijk te bevestigen. Waar het om gaat is de bepaling van effectieve, spaarzame instrumenten voor een duurzaam milieubeleid en nict om een starre verdediging coûte que coûte - van milieubelastingen.

In deze context dient te worden aangestipt dat het milieubeleid in zijn geheel - als uiterst jonge loot van de complexe beleidsboom, die zijn wortels heef in de vastlegging van de individuele vrijheidsrechten en zich vertakt in de talloze regelingen van het maatschappelijk bestel - als zeer dynamisch moet worden beschouwd. Daarvoor kunnen een aantal verklaringen worden gegeven:

- de wetenschappelijke kennis omtrent het milieu neemt toe;

- de technologische mogelijkeden voor milieubescherming nemen toe;

- tegelijkertijd neemt de onzekerheid omtrent de effectiviteit van milieumaatregelen eerder toe dan af.

Milieubelastingen zijn, met name met betrekking tot deze onzekerheid, geen uitzondering. daarom is onderzoek naar de effectiviteit van milieubelastingen in teamverband door ecologen, milieutechnologen en economen dringend gewenst.

In de derde plaats is onderzoek naar de maatschappelijke positic van milieubelastingen dringend noodzakelijk. Ik heb al enkele malen op het vraagstuk van de "fiscale omweg" gewezen, zonder er nader op in te zijn gegaan. In een dergelijk onderzoek zouden de volgende punten aan de orde kunnen komen:

- Worden milieubelastingen vanuit een maatschappelijk standpunt als een „straf“ opgevat? In dat geval dreigt het milieubeleid in slecht vaarwater te geraken. De sympathie van de publieke opinie voor milieubelastingen is dan verdwenen en de kans op een maatschappelijke ondersteuning van milieubelastingen is verkeken.

- De „fiscale omweg“ impliceert dat de wetgever over de besteding van de inkomsten van milieubelastingen beslist. Als van te voren vaststaat dat deze inkomsten alleen maar voor milieubelcidsdoeleinden kunnen worden besteed wordt de souvereine macht van de wetgever (= het parlement), vrij over deze imkomsten te beschikken, ondermijnd. Dat gedeelte van de publieke middelen, dat uit milieubelastingen voortvloeit, staat dan niet meer vrij ter dispositie. Juridisch onderzoek moet dan vitwijzen, of een dergelijke regeling grondwettelijk acceptabel is.

- De „fiscale omweg“ impliceert daarenboven, dat de wetgever voldoende geïnformeerd is over de ecologische effectiviteit van het uitgavenbeleid. In de praktijk blijkt dat de wetgever - hoe kan het anders - in termen van beleidsalternatieven denkt, waarover op politieke wijze (meerderheid tegen minderheid) wordt beslist. Objective informatie is slechts een van de vele inputs die deze besluitvorming bepalen. 


\section{Conclusie}

Milieubelastingen zijn nuttig voor het milieubeleid en de economen hebten er belang bij, dit instrument te promoten. Een beschouwing van de praktijk leer dat een vernieuwende aanloop wenselijk is, die - samenvattend - de volgende criteria als richtsnoer neemt:

- ecologische effectiviteit;

- kosten en baten met betrekking tot andere instrumenten van milieubeleid;

- verdelingseffecten;

- maatschappelijke (= democratische) graad van aanvaardbaarheid.

\section{Dankzegging}

Aan het bestuur van de Edmond Hustinx Stichting: zonder Uw besluit omtrent de oprichting van deze leerstoel zou ik hier niet staan. Tien jaar geleden, in 1986, verscheen een brochure met als titel: „Edmond Hustinx 1898-1984 - Een biografie van de oprichter en naamgever van de Stichting Edmond Hustinx, uitgegeven bij gelegenheid van het vijfentwintigjarig bestaan van de stichting in 1986".

Op bladzijde 27 lezen we: „Als directeur van de fabriek [de Zeepfabriek Hustinx NV] was Edmond Hustinx een merkwaardig manager: hij stimuleerde als een der eerste fabrikanten het hergebruik van afvalstoffen. Hij noemde dit, naar een term uit de filmwereld, coproductie." Hedentendage zou men kunnen geneigd zijn op te merken dat hij inderdaad een eenzame pionier op dat gebied was. Blijkbaar had Edmond Hustinx toentertijd zelfs geen behoefte aan een afvalstoffenwet of een soortgelijke EG-Richtlijn om zijn ondernemersbeleid in de richting van een hergebruik van afvalstoffen te sturen. Ik vraag me af wat Edmond Hustinx vandaag zou hebben gedacht bij het beluisteren van een oratie over het ecologische wel en wee van milieubelastingen. Misschien zou hij gezegd hebben: alles goed en wel, je moet met je tijd meegaan, maar een ondernehmer die zijn eigen concept heeft, kan evengoed zonder. Wie weet?

Waarde collega Backhaus: ons verbindt de overtuiging dat economisch onderzoek wetenschappelijk bezien zijn eigenlijke en feitelijke waarde verkrijgt als de grenzen van de academische disciplines worden overschreden en de stand van de kennis daardoor wordt verbeterd. Dit standpunt goldt tot voor kort als ouderwets: het had geen zin meer, het vervlogen indeaal van de „Universalgelehrter" na te streven. Het milieuonderzoek laat zien, dat dit oude, afgeschreven, ideaal merkwaardig genoeg in de toekomst als een noodzaak dient te worden beschouwd.

In het milieuonderzoek spreekt men over interdisciplinaire samenwerking, holistische analyse, synergie van milieuwetenschap, milieumanagement en analyse van de effectiviteit 
van milieumaatregelen. „Universalgelehrte“ kunnen we niet meer worden, maar het lijkt mij wenselijk, wetenschap en praktijk van het milieubeheer nader tot elkaar te brengen. Het ziet ernaar uit dat daartoe aan deze Universiteit mogelijkheden bestaan.

Aan de studenten: „Milieueconomie is een bijzonder vak, eens iets anders. U houdt zich nogal met de praktijk van het milieubeleid in het bedrijfsleven bezig, dat is toch wel interessant. Het is een keuzevak en we waren nieuwsgierig." Dat zijn enkele uitspraken van studenten die ik in de herfst van het jaar 1995 opgevangen heb. Ik heb uit deze en andere gelijkaardige opmerkingen geleerd dat milicucconomic en milieubeleid - ook in het kader van de bedrijfseconomie - enerzijds een toekomst hebben en anderzijds beter in het onderwijs zouden kunnen geïntegreerd worden. Milieubelastingen en andere instrumenten van milieubeleid, met name het eco-audit-systeem van de EG zijn tenslotte factoren die de kosten, maar ook de baten en de kans op een durzame ontwikkeling van het bedrijfsleven en de economie in zijn geheel beïnvloeden. Het lijkt me nuttig in de toekomst daaraan meer aandacht te besteden.

Ik heb gezegd. 